\title{
Study on Toxic Effects of Lead Acetate on Cerebellar Cortical Tissue of Adult Albino Rats and the Role of Vitamin E as a Protective Agent.
}

\author{
Samira M. Saleh ${ }^{1}$ and Fatma Y. Meligy ${ }^{2}$ \\ ${ }^{1}$ Forensic medicine \& clinical toxicology department, Faculty of medicine, South Valley University, Egypt. \\ ${ }^{2}$ Histology department, Faculty of medicine, Assiut University, Egypt.
}

\begin{abstract}
Lead is a common industrial poison that persists in the environment and has many toxic effects on different organs \& tissues especially on the central nervous system. This study aimed to investigate the effects of lead administration on cerebellar cortex of adult male albino rats and the possible protecting effects of vitamin E. Materials and Methods: Forty male albino rats, (160 $\pm 10 \mathrm{~g}$ weight) were divided into four groups, ten rats each. In the control group rats were received distilled water daily, $2^{\text {nd }}$ group rats were given $30 \mathrm{mg} / \mathrm{kg}$ lead acetate dissolved in distilled water orally daily for two months, $3^{\text {rd }}$ group rats were pretreated by $100 \mathrm{mg} / \mathrm{kg}$ vit. E orally 6 hours before administration of lead acetate by the same dose as group 2 for two months, the $4^{\text {th }}$ group rats were given the same dose of lead acetate then withdrawal was done for one month. Tissue specimens then prepared for light and electron microscopic examinations. The results: By light microscope, in rats treated with lead, the number of Purkinje cells showed a significant decrease in comparison to control group, and appeared shrunken, distorted in shape with irregular nuclei, while in rats treated with lead and vitamin E, there was marked improvement of these alterations. Electron microscopic examination showed Purkinje cells with ill defined nucleus, vaculated or rarified cytoplasm and small electron dense mitochondria. Granular cells showed vaculated cytoplasm and mitochondria with destroyed cristae. In case of vitamin E administration, marked protection against these changes was observed, while the withdrawal group showed very little or no improvement.
\end{abstract}

\begin{tabular}{l|l} 
Keywords & Lead acetate, cerebellum, vit. E, protective, withdrawal, ultrastructure.
\end{tabular}

\section{Introduction}

$\mathrm{L}$ ead $(\mathrm{Pb})$ is a highly toxic heavy metal that persists in the environment and the human body and can disrupt neurological \& other biological body functions ( Bauchi et al., 2016).chronic poisoning by it is one of the major public health hazards especially in developing countries (Flora et al., 2012).

Small amount of lead is excreted in urine and the rest accumulates in various body tissues, mainly the (CNS) which may result in structural changes that can persist even after lowering of its blood level (Sidhu and Nehru, 2004; Taib et al., 2004; Flora et al., 2006; Ibrahim et al., 2012).

Lead was reported to produce oxidative stress by generating release of reactive oxygen species (ROS) such as superoxide radicals, hydroxyl radicals, hydrogen peroxide and lipid peroxides which increase oxidative damage of cellular materials (Ercal et al., 2001 and El-Nekeety et al., 2009).

Depending on the observation that free radicals were generated during the pathogenesis processes induced by lead, it was presumed that supplementation of antioxidants will interrupt or minimize the damaging effects of lead and improve the effects of chelating agents (Flora et al., 2003).

Vitamin E is a lipid soluble membrane-bound antioxidant which protects cell membrane against oxidative stress (Soylu et al., 2006), and has powerful neuro-protective effects (Crouzin et al. 2010).

\section{Aim of work}

To investigate the toxic effects of lead on cerebellar cortex of albino rats and to evaluate the possible protecting role of vit. E.

\section{Materials and methods \\ -Animals}

Forty adult male albino rats weighing $160 \pm 10 \mathrm{~g}$. were used. Rats were obtained from the Animal House of Assiut University, Egypt. Animals were housed in standard conditions and fed on normal diet and water ad libitum.

* Rats were divided into four groups as the following:

Group I (control): 10 male albino rats had received 2 $\mathrm{ml}$ distilled water by oro-gastric tube daily for 2 months. 
Group II (treated): 10 male albino rats had received lead acetate in a dose of $30 \mathrm{mg} / \mathrm{kg}$ which equals $1 / 20$ th of LD50 according to ( Sujatha et al., 2011), dissolved in $2 \mathrm{ml}$ distilled water by oro-gastric tube daily for 2 months.

Group III (Lead + vit. E): 10 male albino rats had received $100 \mathrm{mg} / \mathrm{kg}$ vit. E according to (Bashandy 2006) orally 6 hours before administration of lead acetate by the same dose as group II for two months

Group IV (withdrawal): 10 male albino rats were given the same dose of lead acetate like group II then withdrawal was done for one month.

Chemicals: Lead acetate was purchased from Hemajet company, Egypt and Vitamin E capsules were obtained from PHARCO pharmaceuticals

\section{Methods}

*Light microscopic examination: After the animals were sacrificed, the skull was opened and the two cerebellar hemispheres were removed then fixed in $10 \%$ formalin. After the fixation the samples were dehydrated in a graded series of ethanol, and embedded into paraffin. Blocks of samples were sectioned on a microtome (5-7 um) thick sections and stained with haematoxylin and eosin (H\&E) according to Bancroft and Gamble (2007).

* Semithin \& Electron microscopic examination: 4 rats from each group were used, they were perfused intracardially with $4 \%$ glutaraldehyde in cacodylate buffer ( $\mathrm{pH}$ 7.4) for 24 hours and then fixed in 1\% osmium tetroxide in phosphate buffer for 2 hours. Semithin sections (0.5-1um) were prepared using ultramicrotome and stained with toluidine blue according to Gupta et al. (2007) then examined by light microscope.

Ultrathin sections $(50-80 \mathrm{~nm})$ from selected areas of trimmed blocks were made and collected on copper grids. The ultrathin sections were then stained with uranyle acetate \& lead citrate for 10 minutes according to (Hayat 2000), and examined by transmission electron microscope (Jeol EM) in the unit of electron microscope, Faculty of Medicine, Assiut university.

\section{Morphometric study}

The number of Purkinje cells per field was counted in the 4 animal groups under the study through using a computer assisted image analyzer in the histology department, faculty of medicine, Assiut University. Measurement was done viewing semithin sections by x100 objective lens in five non overlapping fields in ten randomly chosen sections from four different animals for each group. The data then analyzed using statistical package for the social science (SPSS, version 22).

\section{Results}

Table 1 shows that the number of Purkinje cells in the group of animals treated with $\mathrm{Pb}$ and in the withdrawal group was significantly lowered in comparison to control. While the group treated with $\mathrm{Pb}$ and vitamin $\mathrm{E}$ showed no statistical difference in comparison to control.

\section{Light \& electron microscopic results Group I (Control):}

A) By light microscope: H\&E and toluidine blue stained sections showed normal histological structure in the form of outer molecular layer (ML) which is mainly formed from fibers with few small stellate cells and basket cells. Middle Purkinje cells in the Purkinje layer (PL) are arranged in one row of large pyriform or flask shape cells, with clear nuclei, prominent nucleoli and cytoplasm. The inner most layer contain the granular cells (GL) which are closely packed rounded small cells

B) By electron microscope: the cerebellar cortex showed Purkinje cell body with well defined nucleus with electron dense nucleolus, numerous mitochondria, free ribosomes, Golgi bodies and strands of rough endoplasmic reticulum (RER).

Group II (treated with lead):

A) By light microscope: by $H \& E$ stain the Purkinje layer showed shrinkage of the Purkinje cells (empty spaces around them) with increased acidophilia, while toluidine blue stained sections showed distorted shape Purkinje cells and their nuclei appear irregular.

B) By electron microscope: the Purkinje cells appear with irregular ill-defined nucleus with increased condensation of nuclear chromatin and indentations of the nuclear envelope. The cytoplasm is rarified with small dense mitochondria and the cells are surrounded by empty spaces. Granular cells show increased condensation of nuclear chromatin inside their nuclei. The nuclei are surrounded by a shell of vacuolated cytoplasm, the mitochondria appear with destroyed cristae.

\section{Group III ( treated with Lead + vit. E):}

A) By light microscope: H\&E stained sections showed almost normal appearance of (ML) (PL) (GL). Toluidine blue stained sections showed Purkinje cells with vesicular nucleus and prominent nucleolus

B) By electron microscope: the Purkinje cells appeared with euchromatic nucleus and prominent electron-dense nucleolus. The cytoplasm showed cisternae of rough endoplasmic reticulum (RER) around the nucleus, and some dilated cisternae of perinuclear Golgi. Granular cells appeared with rounded heterochromatic nuclei, surrounded by a shell of cytoplasm containing free ribosomes, strands of rough endoplasmic reticulum (RER), and mitochondria Group IV ( withdrawal):

A) By light microscope: H\&E stained sections showed irregular Purkinje cells with darkly stained nuclei \& cytoplasm, while the molecular and the granular layers are apparently normal. Toluidine blue stained sections show Purkinje cells which appear irregular in size and shape with darkly stained nuclei and cytoplasm. The molecular layer revealed perineuronal spaces around stellate cells and basket cells while the granular layer was apparently normal.

B) By electron microscope: ultra-structure examination revealed Purkinje cells with euchromatic nuclei which shows heterochromatin. The cytoplasm shows free ribosomes, strands of rough endoplasmic reticulum , free lysosomes, areas of vacuolated cytoplasm, and mitochondria with destroyed cristae. 
Table (1): comparison between number of Purkinje cells in the control group of animals and each of the other four groups

\begin{tabular}{|l|l|l|l|l|}
\hline & $\begin{array}{l}\text { Group I } \\
\text { (Control) }\end{array}$ & $\begin{array}{l}\text { Group II } \\
\text { (Treated) }\end{array}$ & $\begin{array}{l}\text { Group III } \\
\text { (Lead +vit.E) }\end{array}$ & $\begin{array}{l}\text { Group IV } \\
\text { (withdrawal) }\end{array}$ \\
\hline Mean \pm SD & $8.23 \pm 1.87$ & $5.93 \pm 1.57$ & $7.42 \pm 1.73$ & $6.36 \pm 1.65$ \\
\hline P-value & & $0.001^{*}$ & 0.078 & $0.031^{*}$ \\
\hline
\end{tabular}

Student-t test where $P<0.05=$ significant value

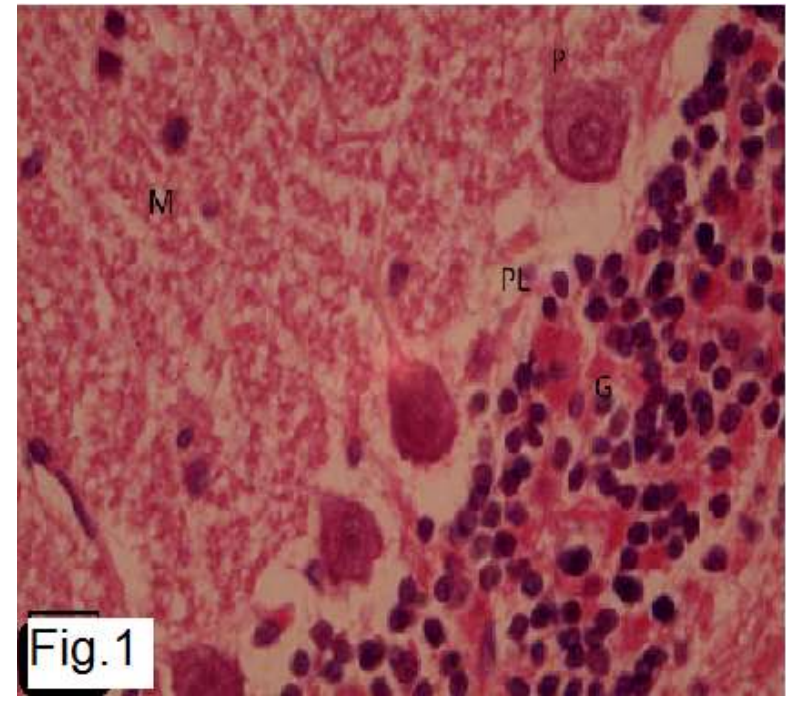

Fig 1: A photomicrograph of a section in the cerebellar cortex of a rat from the control group showing a molecular layer (M) formed of few small stellate cells and basket cells. Purkinje cells (P) in the Purkinje cell layer (PL) are arranged in one row of large pyriform somata with prominent nucleoli and cytoplasm along the outer margin of the granular layer (G), whereas the granular layer shows tightly packed small rounded cells. H\&E X 1000

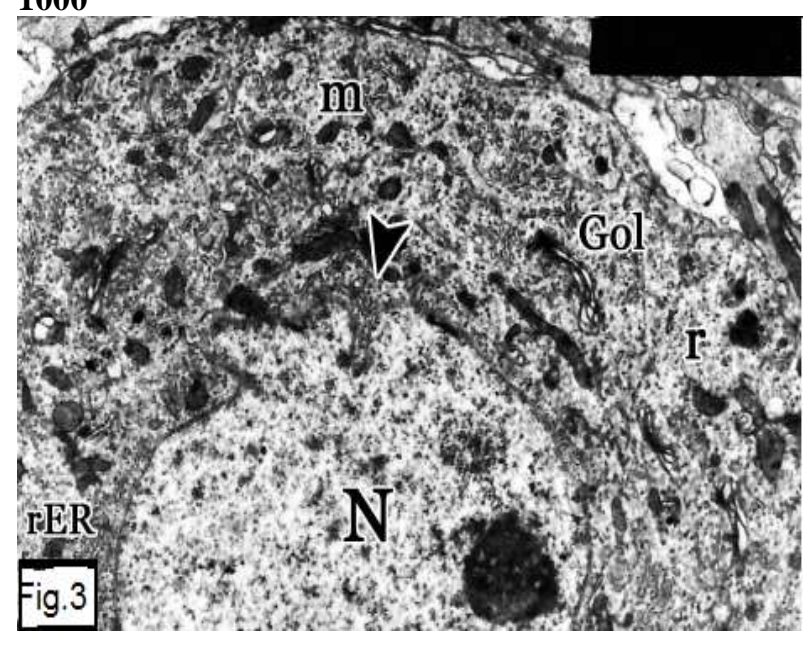

Fig3: An electron micrograph in the cerebellar cortex of control rat showing; part of Purkinje cell body. Well defined euchromatic nucleus (N) with electron dense nucleolus is seen; numerous mitochondria (m), free ribosomes (r), Golgi bodies (Gol) and strands of rough endoplasmic reticulum (rER) can be observed. Notice: The nuclear cap region (arrow head). (X 5000).

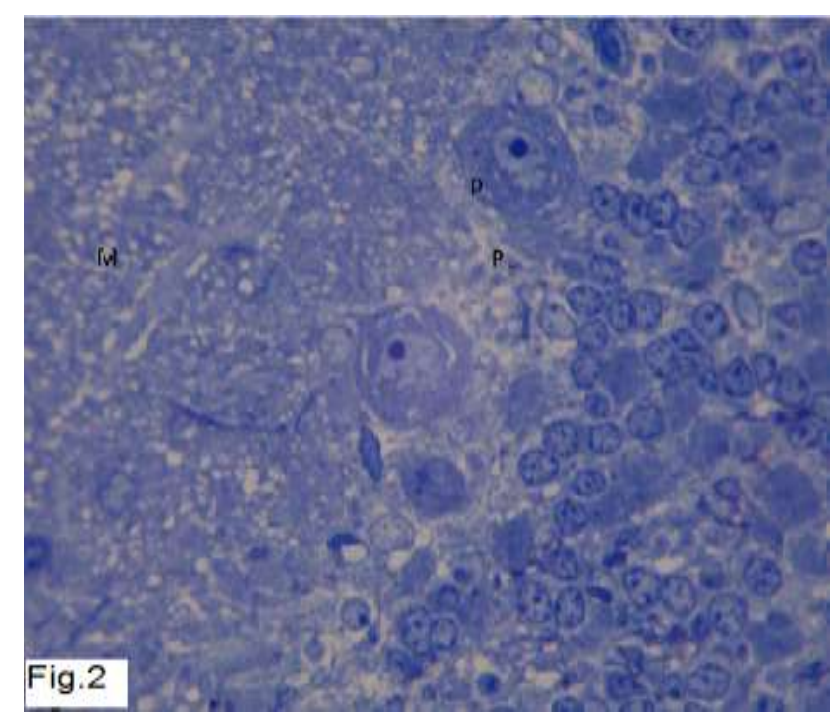

Fig 2: A photomicrograph of a section in the cerebellar cortex of a control rat showing the molecular layer (M), the Purkinje cell layer (PL), and the granular layer (G). Purkinje cells $(P)$ are arranged in one row of large pyriform somata with clear vesicular nuclei and prominent nucleoli along the outer margin of the granular layer. Toluidine blue $\mathrm{X}$ 1000

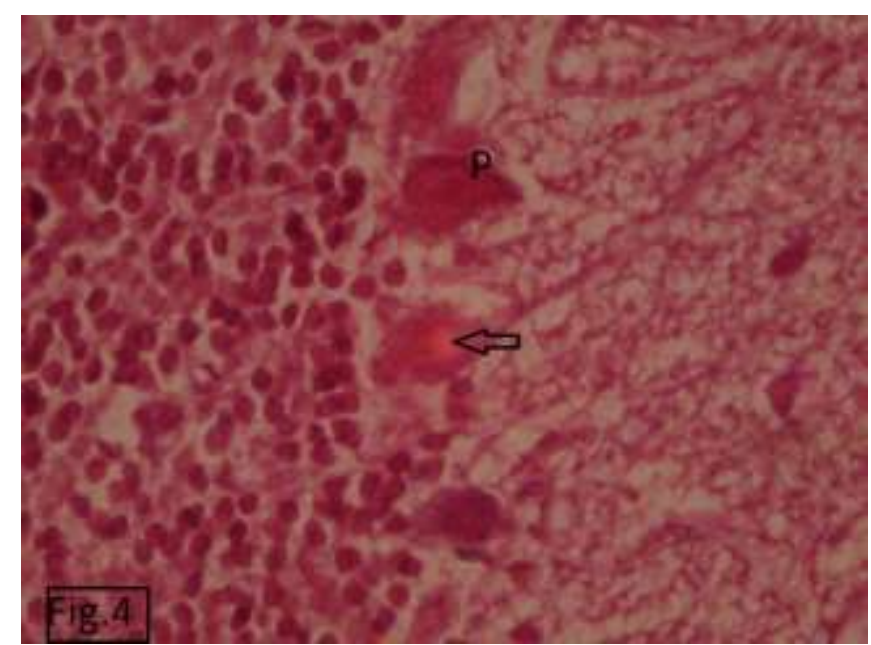

Fig 4: A photomicrograph of a section in the cerebellar cortex of a Lead treated group showing part of the PL with shrinkage of the Purkinje cells (P). Their nuclei appear irregular. Notice the increased acidophilia (arrow) (H\&E x 1000). 


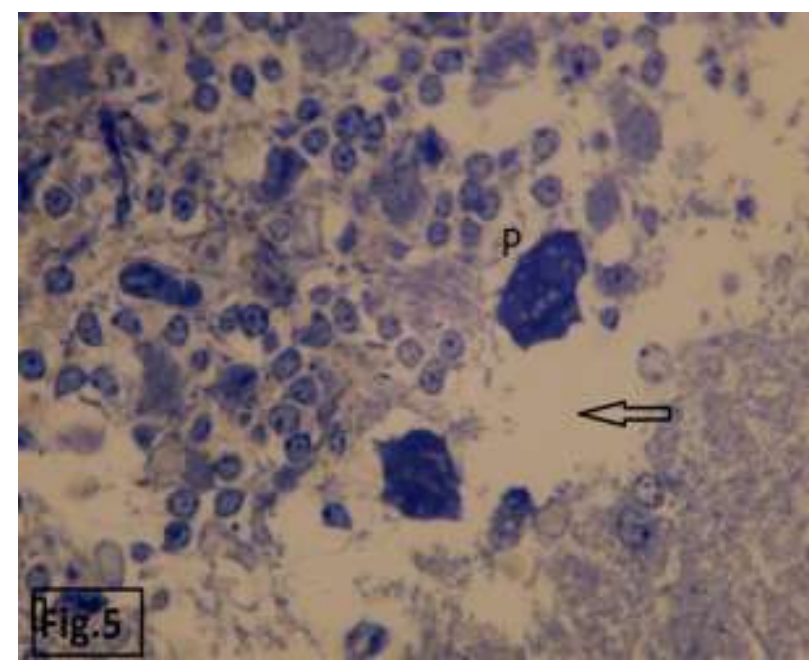

Fig 5: A photomicrograph of a semithin section in the cerebellar cortex of a lead-treated adult albino rat showing Purkinje cells (P) with distorted shape and irregular nucleus . Notice the empty spaces around them. (arrow)(Toluidine blue $x$ 1000).

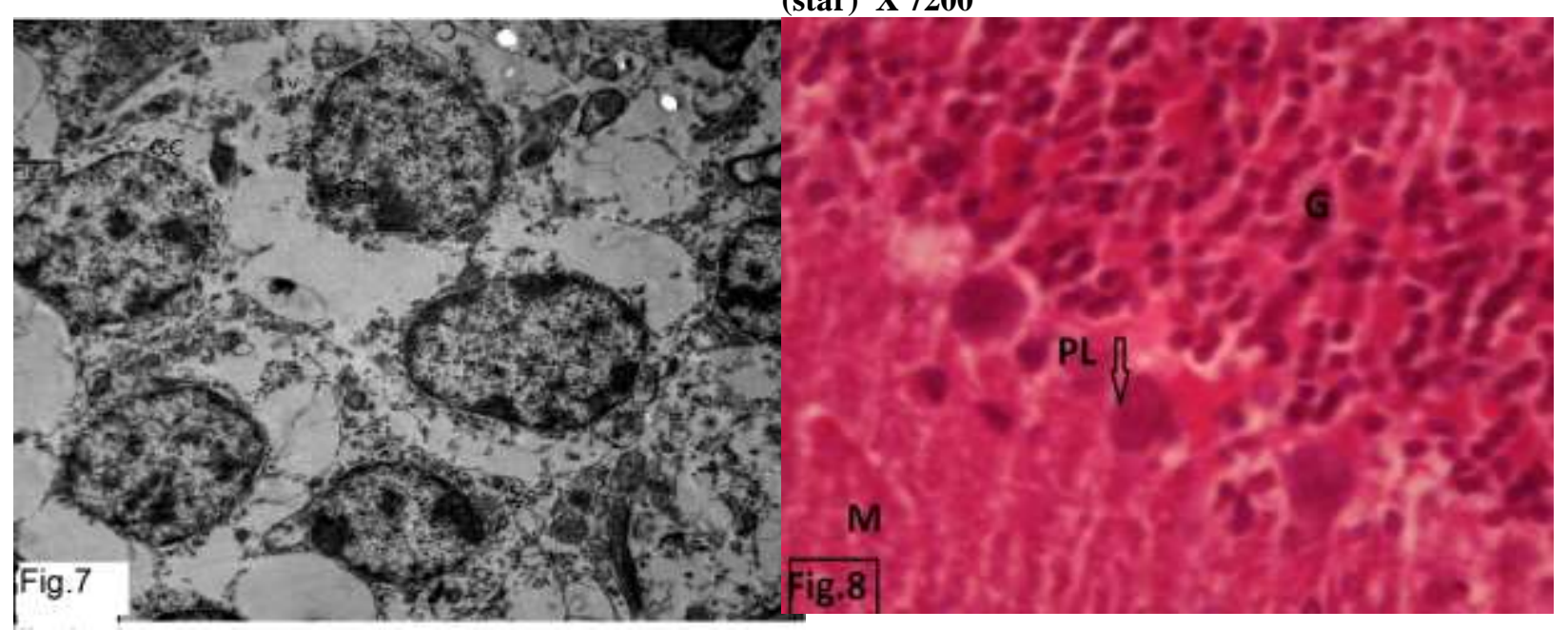

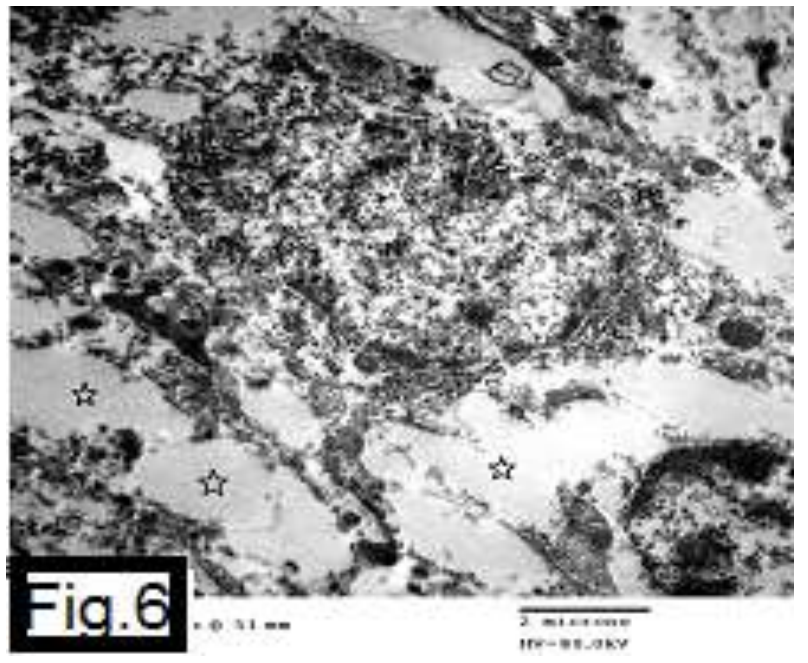

Fig 6: An electron micrograph of ultrathin section in the cerebellar cortex of a rat treated with $\mathrm{Pb}$ showing Purkinje cell that has an irregular euchromatic nucleus $(\mathrm{N})$ with increased condensation of nuclear chromatin and indentations of the nuclear envelope. The cytoplasm is rarified with small dense mitochondria. The cell is surrounded by empty spaces (star) X 7200
Fig 7: An electron micrograph of an ultrathin section in the cerebellar cortex of a lead -treated rat showing granular cells (GC) with increased condensation of nuclear chromatin (arrows) inside their nuclei $(\mathrm{N})$. The nuclei are surrounded by a shell of cytoplasm showing free ribosomes (r), mitochondria (M) with destroyed cristae, and areas of vacuolated cytoplasm (v). $\times 4800$.
Fig 8: A photomicrograph of a section in the cerebellar cortex of a rat treated by both lead and Vit E. showing almost normal appearance of Purkinje cells (arrow) in the Purkinje cell layer (PL). (M) layer and the granular (G) layer show an almost normal appearance.

H\&E, $\times 1000$. 


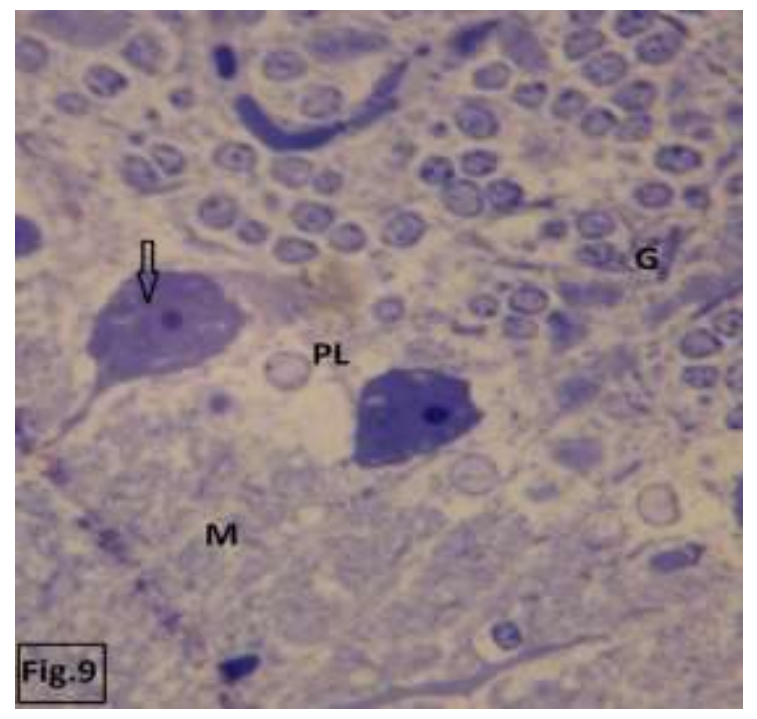

Fig 9: A photomicrograph of a section in the cerebellar cortex of a rat treated by both lead and Vit E. showing Purkinje cells with a vesicular nucleus and a prominent nucleolus (arrow) in the Purkinje cell layer (PL). Note the molecular (M) and granular $(\mathrm{G})$ layers. Toluidine blue, $\times 1000$.

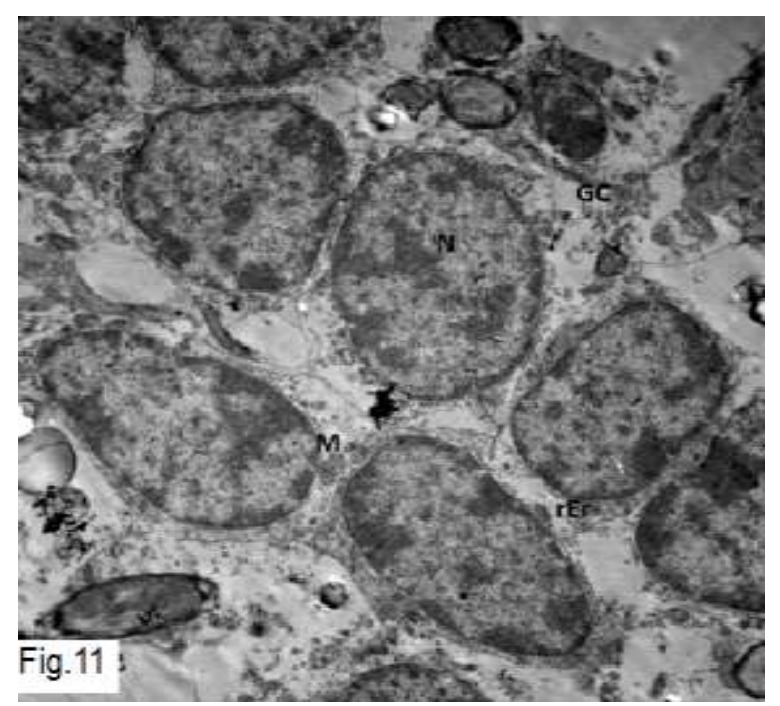

Fig 11: An electron micrograph of an ultrathin section in the cerebellar cortex of a rat treated by both lead and Vit $E$. showing granular cell layer (GC) with their rounded hetero-chromatic nuclei (N) surrounded by cytoplasm which shows free ribosomes $(r)$, rough endoplasmic reticulum (rER), and mitochondria $(\mathrm{M}) . \times 4800$

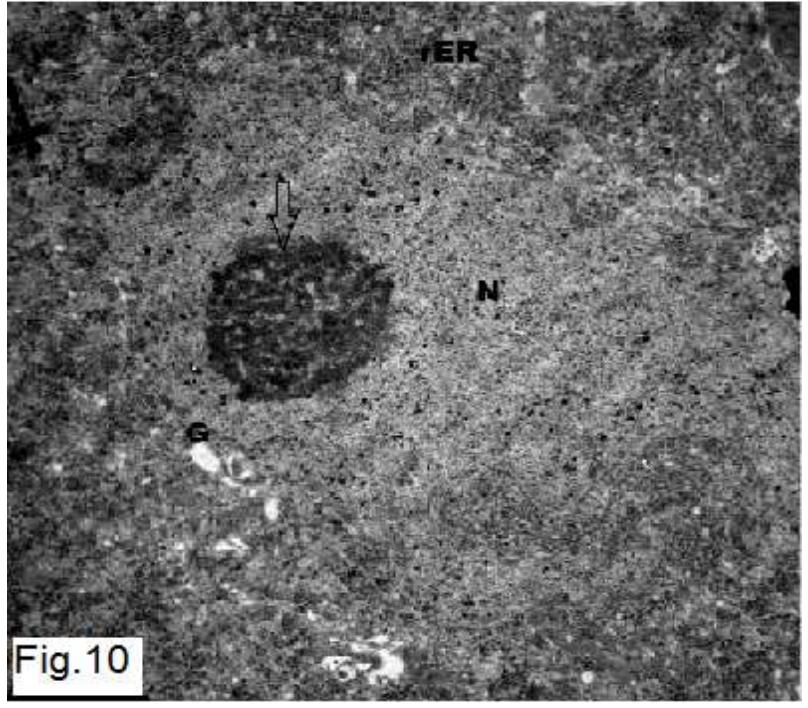

Fig 10. An electron micrograph of an ultrathin section in the cerebellar cortex of a rat treated by both lead and Vit E. showing a Purkinje cell (PC) with a euchromatic nucleus (N) and a part of a prominent electron-dense nucleolus (arrow head). The cytoplasm shows cisternae of rough endoplasmic reticulum (rER) around the nucleus, and some dilated cisternae of perinuclear Golgi (G). x7200

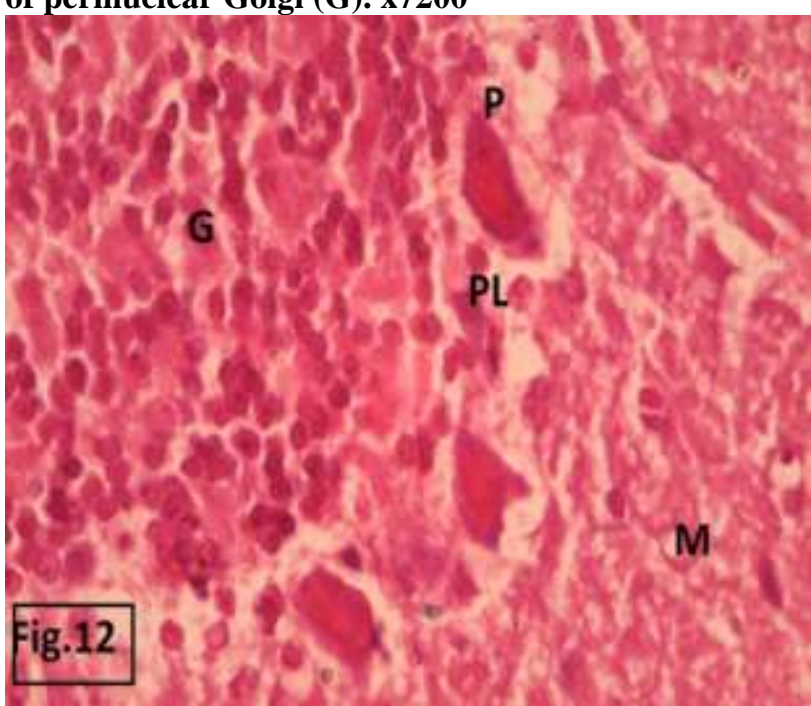

Fig 12: A photomicrograph of a section in the cerebellar cortex of the withdrawal group showing some Purkinje cells (arrows) that appear irregular and darkly stained. The molecular layer $(M)$ and The granular layer (G) are apparently normal. H\&E, × 1000. 


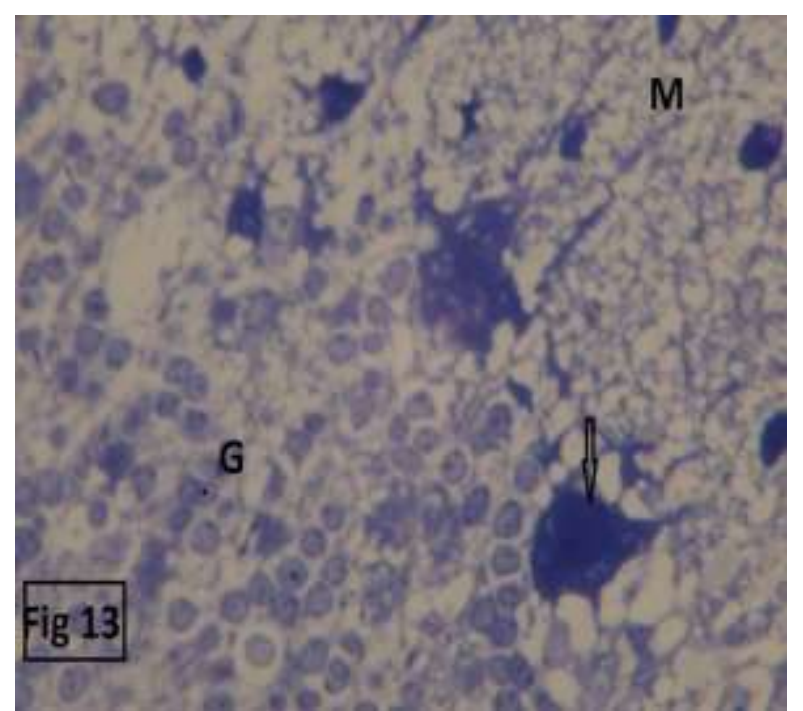

Fig 13: A photomicrograph of a section in the cerebellar cortex of the withdrawal group showing Purkinje cells (arrows) that appear irregular in size and shape with darkly stained nuclei and cytoplasm. The molecular layer (M) shows perineuronal spaces The granular layer (G) is apparently normal. Toluidine blue $\times 1000$.

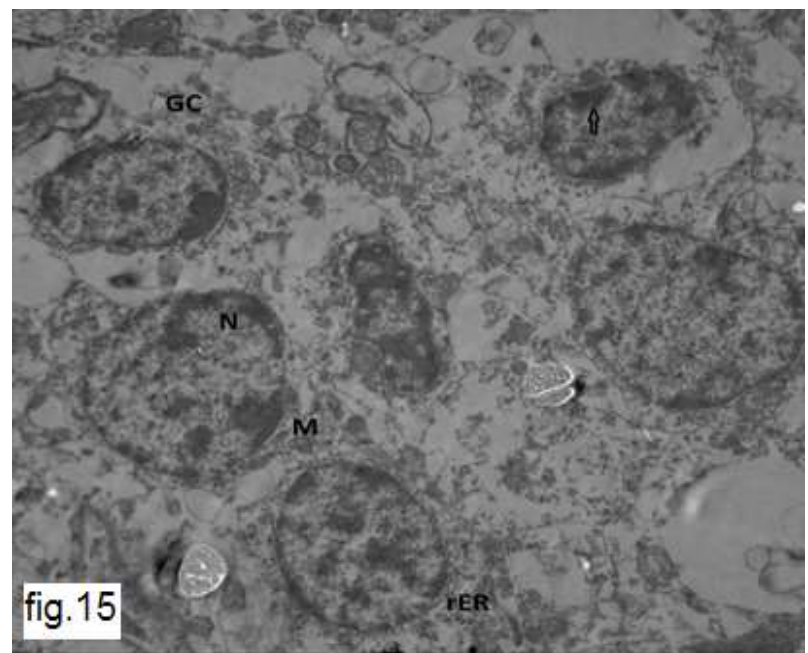

Fig 15 An electron micrograph of an ultrathin section in the cerebellar cortex of a rat of the withdrawal group showing granule cells (GC) with rounded heterochromatic nuclei (N) showing increased condensation of nuclear chromatin (arrow). The nuclei are surrounded by a shell of cytoplasm containing free ribosomes ( $r$ ), areas of vacuolated cytoplasm (v), and mitochondria (M) with destroyed cristae. $\times \mathbf{4 8 0 0}$

\section{Discussion}

The neurotoxic effects of high level lead exposure has been proved in both animals and human, where the damage involves peripheral and central nervous systems (Brenet, 2006). Many factors account for the neurotoxic effects of lead; they include integrity of blood-brain barrier, lead-binding proteins, cellular scavengers (e.g. glutathione) and interactions with other micro-nutrients (Sidhu and Nehru, 2004)

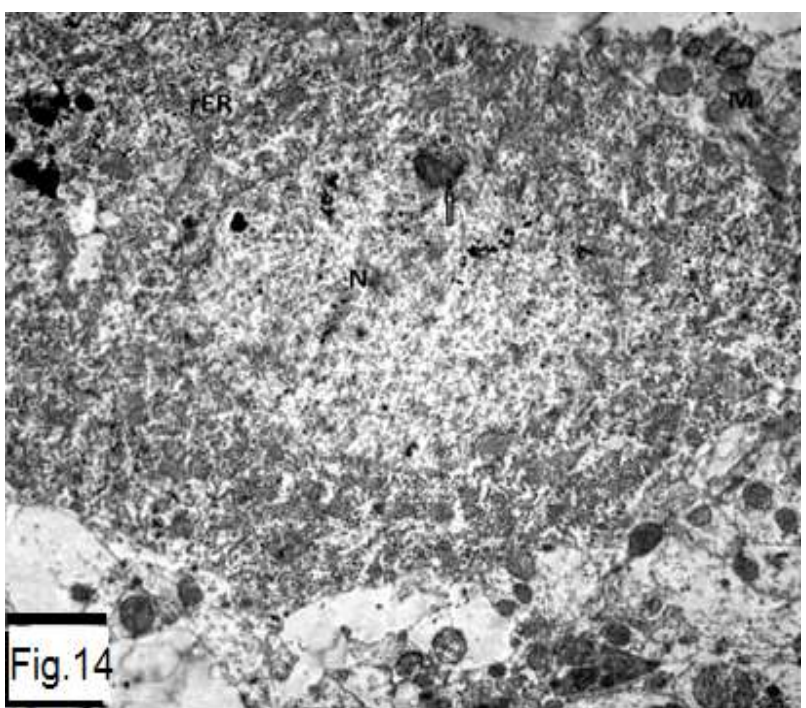

Fig 14: An electron micrograph of an ultrathin section in the cerebellar cortex of a rat of the withdrawal group showing a Purkinje cell (PC) with a normal nucleus $(\mathrm{N})$ that shows heterochromatin (arrow). The

cytoplasm shows free ribosomes (r), strands of rough endoplasmic reticulum (rER), lysosomes (Ly), and mitochondria (M) with damaged cristae .X 4800

Vitamin E is the most important lipophilic antioxidant which stays mainly in the mitochondria thus helping to maintain membrane stability. Also, it decreased the cell death which is due to free radicals. The ingestion of vitamin $\mathrm{E}$ gives a protection against lipid peroxidation through its anti-oxidant action (Serbecic and Beutelspacher, 2005)

In the present study, lead induced damage and disorganization in Purkinje cells was evident. By 
light microscope they were shrunken with distorted shape and their nuclei appear irregular. Ultrastructural examination proved the Purkinje cells damage in the form of irregular euchromatic nucleus, rarified cytoplasm, the mitochondria are small dense with destroyed or dilated cristae and the cells are surrounded by empty spaces. Alterations of Granular cells in the form of increased condensation of nuclear chromatin, the nuclei are surrounded by a shell of vacuolated cytoplasm, and the mitochondria appeared with destroyed cristae were also detected.

These findings are in agreement with (Engin Deveci, 2006), who reported that when rats received lead acetate in their drinking water for 60 days degeneration in the neuron cells was evident. The histological findings were also similar to those reported by Villeda Hernandez et al., (2006), Macauley et al., (2008), Amal and Mona (2009), Sohair et al. (2010), Musa et al. (2012) and Fakunle et al. (2013). Changes in neuronal cells observed in this study could be explained by the generation of reactive oxygen species, and depletion of antioxidant reserves. Lead exposure inactivates glutathione molecule (important endogenous antioxidant) by binding of its sulfhydryl group directly (Pajović et al., 2003) and (Sanders et al., 2009). Zhu et al. (2006) and Mattson et al. (2008) reported that Mitochondrial dysfunction and distortion have been recorded in many neurodegenerative diseases which associated with oxidative damage

On the other hand, the animals treated with $\mathrm{Pb}$ and vitamin $\mathrm{E}$ revealed marked improvement in the altered histological architecture of cerebellar cortex, whereby light microscope the purkinje, molecular and the granular cell layers appeared almost normal, while by electron microscope the purkinje cells appeared with euchromatic nucleus, normal prominent nucleolus, strands of RER in the cytoplasm and some dilated Golgi cisternae around nucleus. Nearly similar findings were reported by Amal and Mona (2009) who recorded that the co-treatment of rats by $\mathrm{Pb}$ and antox (mixture of vitamins E, C, A and selenium) prevented most of the histopathological distortion. The mild histological alteration in cerebellar cortex of rats treated by $\mathrm{Pb}$ and vitamin E when compared with the marked distortion in rats treated with $\mathrm{Pb}$ alone is a powerful indicative on the anti-oxidant and the neuro-protective effects of vitamin E. Our results coincide with Crouzin et al. (2010) who stated that the pretreatment of hippocampal neurons of rats by vitamin $\mathrm{E}$ will give a long lasting protection against oxidative damage induced by $\mathrm{Fe}^{++}$ ions by preventing $\mathrm{Ca}^{++}$entry to neuronal cells. Also Alzoubi et al. (2012) reported that vitamin E is a strong antioxidant which has a neuro-protective effect on the brain against cognitive impairment which resulted from chronic sleep deprivation. The findings of this study are in line with Rao and Sharma (2001) who mentioned that vitamin $\mathrm{E}$ has a protective antioxidant effect against mercury induced toxicity on male reproductive system, while Gulec et al. (2006) reported that vitamin E give a protection against oxidative damage induced by formaldyhyde on liver tissue and plasma of rats. Bashandy (2006) concluded that the co-administration of both vitamin $\mathrm{E}$ and $\mathrm{C}$ protects the liver against lead induced lipid peroxidation

Regarding the withdrawal group of rats in which cessation of exposure was done for one month after 2 months treatment by lead, the ultrastructure examination revealed partial recovery of purkinje cells and granular cells, but most of purkinje cells have permanent $\mathrm{Pb}$ induced alterations. The persistence of degenerative changes in purkinje cells after $\mathrm{Pb}$ withdrawal can be explained by the specific kinetics, where fraction of lead after absorption is redistributed and stored in bone (Timchalk et al., 2006), then slowly released from bone and redistributed to soft tissues including cerebellar tissue (Kosnett, 2001). These results are in line with Sohair et al. (2010) who found that withdrawal of $\mathrm{Pb}$ resulted in minimal regression in the structural alterations of cerebellar cortex.

\section{Conclusion}

Administration of $\mathrm{Pb}$ to the studied animals has led to morphological alteration in the neuronal cells in the cerebellar cortex, while the co-administration of $\mathrm{Pb}$ and vitamin E resulted in amelioration of these effects to a great extent due to its anti-oxidant activity.

\section{Recommendations}

We recommend more investigations on the neurotoxic effects of lead on laboratory animals and human, with regular administration of vit.E where lead exposure could not be avoided.

\section{References}

Alzoubi KH, Khabour OF, Rashid BA et al. (2012): The neuroprotective effect of vitamin $E$ on chronic sleep deprivation-induced memory impairment: the role of oxidative stress. Behav Brain Res. Jan 1; 226(1):205-210.

Amal EA and Mona HM (2009): Protective effect of some antioxidants on the brain of adult male albino rats, Rattus rattus, exposed to heavy metals. Biosci Res 6(1):12-19.

Bancroft JD and Gamble M (2007): Theory and practice of histological techniques.6th ed. London: Churchill Livingstone.

Bashandy SA (2006): Beneficial effect of combined administration of vitamin $\mathrm{C}$ and $\mathrm{E}$ in amelioration of chronic lead hepatoxicity. Egypt. J Hospt Medic. 23, 371-384.

Bauchi ZM, Kizito D, Alhassan AW et al. (2016): Effect of Aqueous Seed Extract of Nigella Sativa on Lead-Induced Cerebral Cortex Toxicity in Long Evans Rats Bayero. J of Pure and Applied Sciences, 9(1): 48 - 52.

Brent JA (2006): Review of medical toxicology. J Clin Toxicol. 44: 355-355.

Crouzin N, Ferreira MC, Cohen-Solal C et al. (2010) : Neuroprotection induced by vitamin E against oxidative stress in hippocampal neurons: involvement of TRPV1 channels. Mol Nutr Food Res. Apr. 54(4):496-505.

El-Nekeety AA, El-Kady AA, Soliman MS et al. (2009): Protective effect of Aquilegia vulgaris (L.) against lead acetate-induced oxidative stress in rats. Food Chem Toxicol, 47: 22092215. 
Engin Deveci (2006): Ultrastructural effects of lead acetate on brain of rats. Toxicology and Industrial Health 22(10): 419 - 422.

Ercal N, Gurer-Orhan H and Aykin-Burns N (2001): Toxic metals and oxidative stress. Part 1. Mechanisms involved in metal-induced oxidative damage. Curr Top Med Chem, 1:529-539.

Fakunle PB, Ajibade AJ, Oyewo EB et al. (2013): A study of some effects of aqueous extract of neem (Azarancha indica) leaves on the lead acetate induced neurotoxicity in the superior colliculus of adult wistar rats (Rattus norvegicus). Br J Pharm Res, 3(2): 217-231.

Flora G, Gupta D and Tiwari A (2012): Toxicity of lead: a review with recent updates. Interdisciplinary Toxicology, 5(2): 47-58

Flora SJS, Flora G and Saxena G (2006): Environmental Occurrence Health Effects and Management of Lead Poisoning. In: Casas, S.B. and J. Sordo (Eds.), Lead: Chemistry, Analytical Aspects, Environmental Impact and Health Effects. Elsevier, the Nethlands: 158-228.

Flora SJS, Pande M and Mehta A (2003): Beneficial effect of combined administration of some naturally occurring antioxidants (vitamins) and thiol chelators in the treatment of chronic lead intoxication. Chem. Biol. Interact.; 145 (3): 267-280.

Gulec M, Gurel A and Armutcu F (2006): Vitamin E protects against oxidative damage caused by formaldehyde in the liver and plasma of rats. Mol Cell Biochem, 290: 61-67.

Gupta A, Singh M, Ibrahim R et al. (2007): Utility of toluidine blue staining and brush biopsy in precancerous and cancerous lesions. Acta Cytol; 51: 788-794

Hayat MA (2000): Principles and techniques of electron microscopy: biological applications. 4th ed. Edinburgh, UK: Cambridge University Press.

Ibrahim NM, Eweis EA, El-Beltagi HS et al. (2012): Effect of lead acetate toxicity on experimental male albino rat. Asian Pac. J. Trop. Biomed., 2(1): 41-46.

Kosnett MJ (2001): Lead. In: Ford M, Delaney KA, Ling $\mathrm{L}$ and Erickson $\mathrm{T}$, editors. Clinical toxicology: WB Saunders, St. Louis p. 723736.

Macauley SL, Sidman RL, Schuchman EH et al. (2008): Neuropathology of the acid sphingomyelinase knockout mouse model of Niemann-Pick A disease including structurefunction studies associated with cerebellar Purkinje cell degeneration. Exp.Neurol. 214 (2): 181-192.

Mattson MP, Gleichmann M and Cheng A (2008): Mitochondria in neuroplasticity and neurological disorders. Neuron; 60:748-766.
Musa SA, Iliyasu SO, Hamman WO et al. (2012): Preventive activity of Ascorbic Acid on Lead Acetate induced Cerebellar Damage: Medical and Health Sciences Journal, 13: 99-104

Pajović SB, Saičić ZS, Spasić MB et al. (2003): The effect of ovarian hormones on antioxidant enzyme activities in the brain of male rats. Physiol Res. 52:189-194.

Rao MV and Sharma PSN (2001): Protective effect of vitamin $E$ against mercuric chloride reproductive toxicity in male mice Repr Toxicol, 15: 705-712

Sanders T, Liu Y, Buchner V et al. (2009): Neurotoxic effects and biomarkers of Lead exposure: A Review. Res Environ Health 24: 15-45.

Serbecic N and Beutelspacher SC (2005): Antioxidative vitamins prevent lipid-peroxidation and apoptosis in corneal endothelial cells. Cell Tissue Res. 320(3): 465-475.

Sidhu P and Nehru B (2004): Lead intoxication: Histological and oxidative damage in rat cerebrum and cerebellum. J.Trace Elem. Exp. Med. 17(1): 45-53.

Sohair A, Manal A and Aml A (2010): Histological Study on the Effect of Low Level Perinatal Lead Exposure on the Cerebellar Cortex of Adult Male Albino Rat. Egypt. J. Histol. Vol. 33, No. 4, Dec.: 781 - 797.

Soylu AR, Aydogdu N, Basaran UN et al. (2006): Antioxidants vitamin $\mathrm{E}$ and $\mathrm{C}$ attenuate hepatic fibrosis in biliary-obstructed rats. World J Gastroenterol, 40, Nov 14, 12(42):6835-6841.

Sujatha K, Srilatha C, Anjaneyulu Y et al. (2011): Lead acetate induced neurotoxicity in wistar albino rats: A pathological, immunological, and ultrastructural studies. J of pharma and bio science Vol.2, 459-462

Taib NT, Jarrar BM and Mubarak M (2004): Ultrastructural alterations in hepatic tissues of white rats (Rattus norvegicus) induced by lead experimental toxicity. Saudi J. Biol. Sci. 11(1): 11-20.

Timchalk C, Lin Y, Weitz KK et al. (2006): Disposition of lead $(\mathrm{Pb})$ in saliva and blood of Sprague-Dawley rats following a single or repeated oral exposure to Pb-acetate. Toxicology May 1, 222(1-2): 86-94.

Villeda Hernandez J, Mendez Armenta M, Barroso Moguel R et al. (2006): Morphometric analysis of brain lesions in rat fetuses prenatally exposed to low level lead acetate: Correlation with lipid peroxidation. Histol. Histopathol. Jun 21(6):609-617.

Zhu X, Perry G, Moreira PI et al. (2006): Mitochondrial abnormalities and oxidative imbalance in Alzheimer disease. J Alzheimers Dis; 9:147-153. 


\section{الملخص العزبى}

دراسة على التأثيرات السامة لحلات الرصاص على نسيج قشرة المخيخ فى الجرذان البيضاء البالفة ودور فيتامين كعامل وقائي

\section{سميرة محمد صالح ا و فاطمة ياسين عبد المتجلى مليجى}

الرصاص هو مادة صناعية شائعة في البيئة ولها العديد من التأثيرات السامة على أعضاء الجسم والأنسجة المختلفة خاصة على الجهاز العصبي المركزي.

الهدف من اجراء البحث: أجريت هذه الدراسة لفحص تأثيرات تناول خلات الرصاص على قشرة المخيخ للجرذان البيضاء من

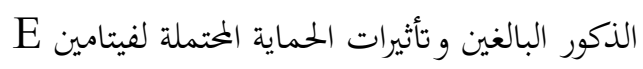

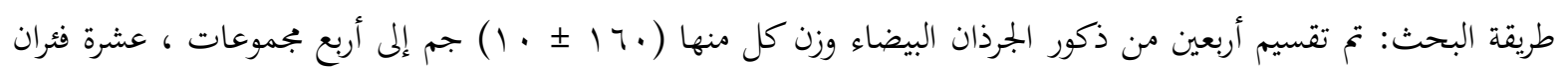

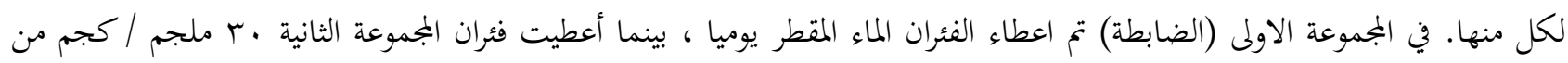

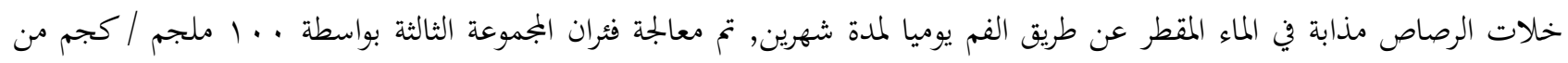
فيتامين E بالفم I ساعات قبل إعطاء خلات الرصاص بنفس جرعة المجموعة الثانية لمدة شهرين ، أعطيت المجموعة الرابعة من الفئران

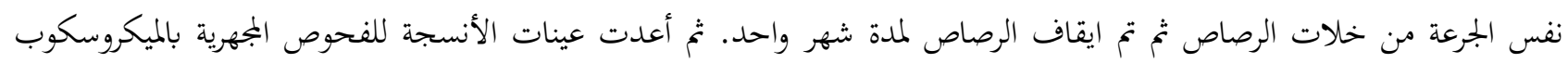
الضوئى والإلكترونى.

النتائج: بالفحص بالميكروسكوب الضوئى في الفئران التي عولجت بالرصاص ، أظهر عدد خلايا بركنج الخفاضًا ملحوظًا مقارنة

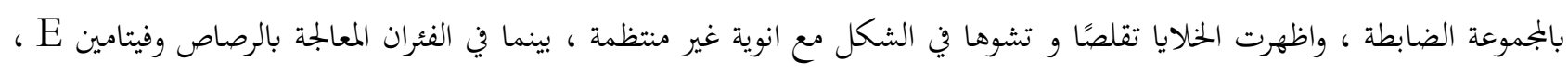
كان هناك تحسن ملحوظ في هذه التغيرات, و بالفحص بالميكروسكوب الإلكترونى ظهرت خلايا بركنج ذات انوية غير واضحة الجدران المبان

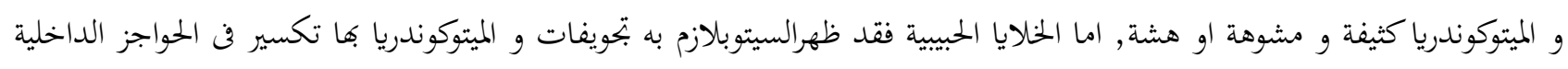

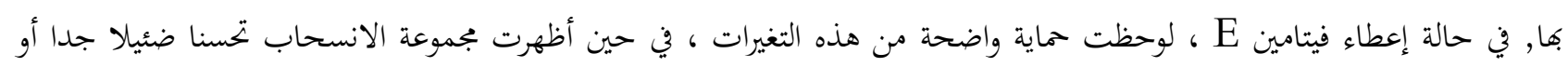

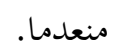

| قسم الطب الثر عي و السهوم الإكلينكية. كلية الطب - جامعة جنوب الو ادى. Y قسم الهستولوجيا - كلية الطب - جامعة أسبوط 